Research Report

\title{
Using Illustrated Books with Surabayan Dialect to Promote Regular Child Dental Visits in East Surabaya Public Health Center
}

\author{
Aryo Dwipo Kusumo ${ }^{1,2}$, Darmawan Setijanto ${ }^{1}$, Titiek Berniyanti' ${ }^{1}$, Ninuk Hariyani ${ }^{1}$, Gilang Rasuna Sabdho \\ Wening $^{1}$, Dini Setiyowati ${ }^{1}$, Retno Palupi ${ }^{1}$, Agung Sosiawan', Aulia Ramadhani, ${ }^{1,2}$, Rovilla Amalia ${ }^{2}$ \\ ${ }^{1}$ Department of Dental Public Health, Faculty of Dental Medicine, Universitas Airlangga, Surabaya, Indonesia \\ ${ }^{2}$ Graduate Student of Health Administration and Policy, Faculty of Public Health, Universitas Airlangga, Surabaya, \\ Indonesia
}

\begin{abstract}
Background: Previous research involving 100 children in the East Surabaya area reported a caries prevalence data of 89.5\% with a Decayed, Missing due to carries, Filled Teeth index (DMFT) value of 5.42 (high category). In January-June 2018, only 373 out of 4,072 school-age children visited the Keputih Public Health Center. The dental visits were motivated out of dental health problems only. Parents, especially mother, should pay attention to their child's dental and oral health because they are in the primary tooth period, which will significantly affect the growth of their permanent teeth. Purpose: The illustration book in Surabayan dialect was the means to disseminate information on dental and oral health for children and parents, particularly mothers, to motivate regular dental visit and prevent dental caries. Methods: The parents received the illustrated book, and they were given some time to read and answer the questions. After that, the mothers were asked to assist their children in filling out the illustration book. The targets were improved understanding on the subject matter, which is dental and oral health, and to motivate the parents and children to have regular dental visit. Results: There was $>75 \%$ increase in understanding of the subject matter before and after the intervention. Conclusion: The intervention successfully improved the parents' understandings in the subject matter, and it was expected to motivate parents and their children to have regular dental visits in Keputih Public Health Center.
\end{abstract}

Keywords: mother and child; local language; dental caries.

Correspondence: Aryo Dwipo Kusumo, Dental Public Health, Faculty of Dental Medicine, Universitas Airlangga. Jl. Mayjen Prof. Dr. Moestopo 47 Surabaya, 60123, Indonesia. Email: aryodkusumo@gmail.com

\section{INTRODUCTION}

Keputih 245 Elementary School is one of the elementary schools located in the East Surabaya area, precisely in Keputih Village, Sukolilo District. Keputih 245 Elementary School is a school with the fourth highest number of students in Sukolilo District. It is a public elementary school, and its closest public health center is Keputih Public Health Center, Surabaya City. ${ }^{1}$ A survey in September 2017 involving 100 children in the East Surabaya area, including Keputih 245 Elementary School reported a caries prevalence data of $89.5 \%$ with a Decayed, Missing due to carries, Filled Teeth index (DMFT index) value of 5.42. According to the caries severity level set by the WHO for children under 12 years old, the DMFT value was categorized as high (4.5-6.5). ${ }^{2}$ In January-June 2018, only 373 out of 4,072 school-age children visited the Keputih Public Health Center. This shows the low percentage of total child dental visitation in the Keputih area, which was only $9.16 \%$ of the total population. ${ }^{3}$ The results of problem prioritisation based on risk factors and correlation test results showed that poor understanding on dental and oral health problems, ${ }^{1}$ low awareness of their child dental health status, ${ }^{2}$ and low motivation to participate in regular dental health visit were the risk factors of the low child dental visitation in Keputih Public Health Center. ${ }^{3}$

Carrying out children's dental care, there are three components that must work together. These components are depicted in the form of a triangle which is known as the pediatric dental triangle. In this triangle, the corners are occupied by the dentist, the family (especially the mother) and the child as the patient is located at the apex of the triangle. The triangles are dynamically interconnected. ${ }^{4}$

Parents, especially mothers, are very influential in maintaining children's health and dental hygiene because children are still dependent on their parents. The attitudes and behavior of the mother who is the closest person to the child has a very significant influence on the attitude and 
behavior of the child in health care. The role of a mother in the dental health of her children is as a motivator, educator and facilitator. The Australian Dental Association also states that mothers are responsible for the health of their children's teeth. ${ }^{5}$

Within Indonesian society itself, visits to the dentist have not become a routine thing especially for children. A visit to the dentist is only carried out if there are complaints from children regarding their teeth. Dental and oral health of children must receive serious attention from parents, especially mothers, even though they are still in the primary tooth period because it will determine the growth of their permanent teeth. However, many parents think that baby teeth are only temporary and will be replaced by permanent teeth, so they often think that damage to baby teeth due to poor oral hygiene is not a problem. ${ }^{6}$

Dental and oral health problems can affect the quality of life both as a children and an adult. In children, severe caries can increase the risk of school absence, and it can affect the learning process and achievement of the child at school. ${ }^{7}$ The American Academy of Pediatric Dentistry (AAPD) and the American Dental Association (ADA) recommend that initial visits to a pediatric dentist should begin within 6 months after eruption of the first primary tooth or 1 year of age. At this visit, the dentist can detect early signs of caries lesions, carry out a caries risk assessment, evaluate tooth development, provide dietary guidance and counseling and provide motivation to parents to adopt oral disease prevention behaviors. ${ }^{8}$ In Indonesian society, visits to the dentist have not become a routine especially for children. The dental visits were motivated out of dental health problems only. Parents, especially mother, should pay attention to their child's dental and oral health because they are in the primary tooth period, which will significantly affect the growth of their permanent teeth. However, many parents think that baby teeth are only temporary and will be replaced by permanent teeth that they often think dental problems to baby teeth due to poor oral hygiene is not a problem. ${ }^{9}$

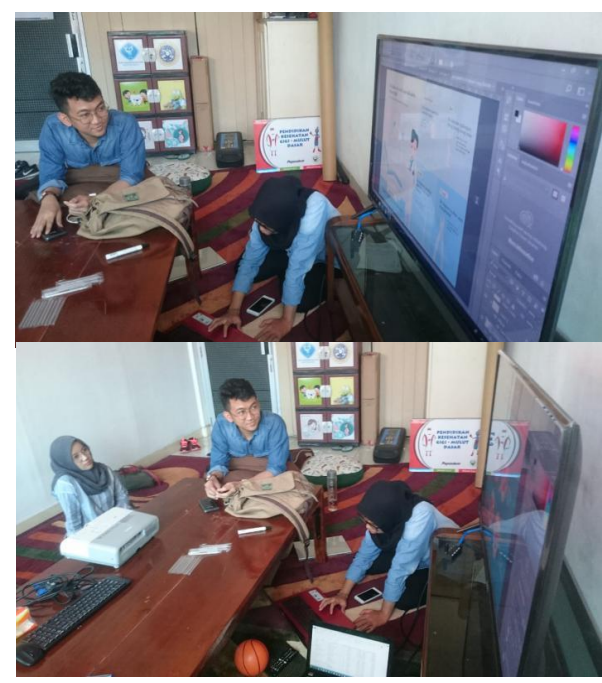

Figure 1. FGD of the book in Surabayan dialect.

\section{MATERIALS AND METHODS}

The illustration book in Surabayan dialect was the means to disseminate information on dental and oral health for children and parents, particularly mothers, to motivate regular dental visit and prevent dental caries. The parents received the illustrated book, and they were given some time to read and answer the questions. After that, the mothers were asked to assist their children in filling out the illustration book. The targets were improved understanding on the subject matter, which is dental and oral health, and to motivate the parents and children to have regular dental visit.

\section{RESULTS}

The community service was initiated with a Focus Group Discussion (FGD)as showed in Figure 1 related on the illustration books in Surabayan dialect for parents and elementary school students. The FGD involved community dental health experts from the Department of Public Dental Health and book illustrators.

The FGD material was referral problems at Keputih 245 Elementary School, which was obtained through preliminary research. The result of this discussion was a book draft in Surabayan dialect, The book promoted dental and oral healthcare in Surabayan dialect. Starting with a topic of teeth in general, followed by why cavities occur, and how to do dental care properly, and the layout design of Surabayan dialect book as seen on Figure 2 and 3.

The books were distributed to 41 parents and students Keputih 245 Elementary School, as well as homeroom teachers (Figure 4). In this activity, the parents received an instruction how to make the most of the book and how to assist their children in filling out the book. This activity was guided by health workers (dentists). As a result that showed in Figure 5 we found $>75 \%$ increase in understanding of the subject matter in parents.

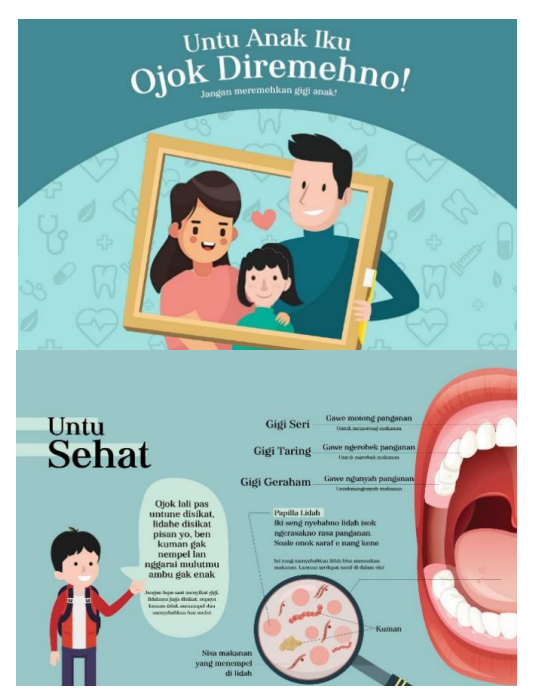

Figure 2. The book cover and illustrations for parents. 


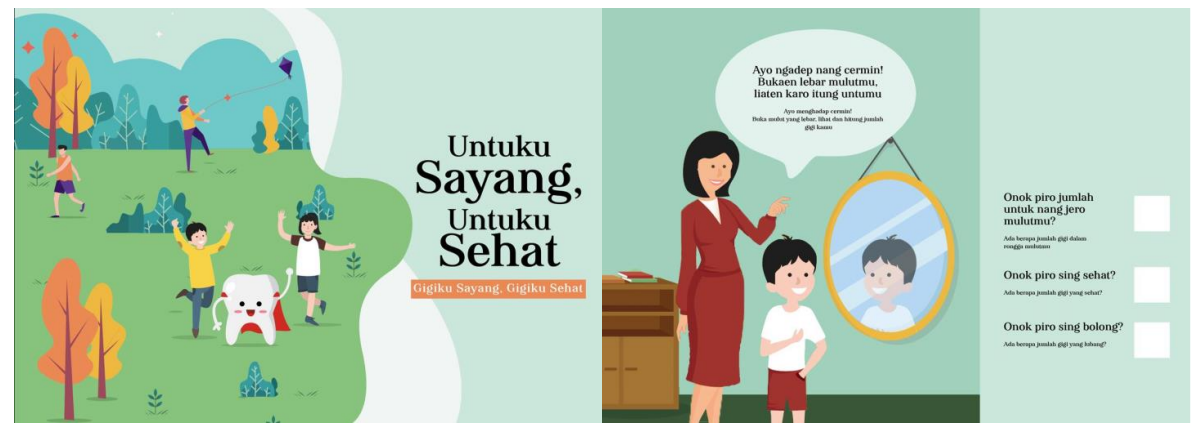

Figure 3. The book cover and illustrations for children.

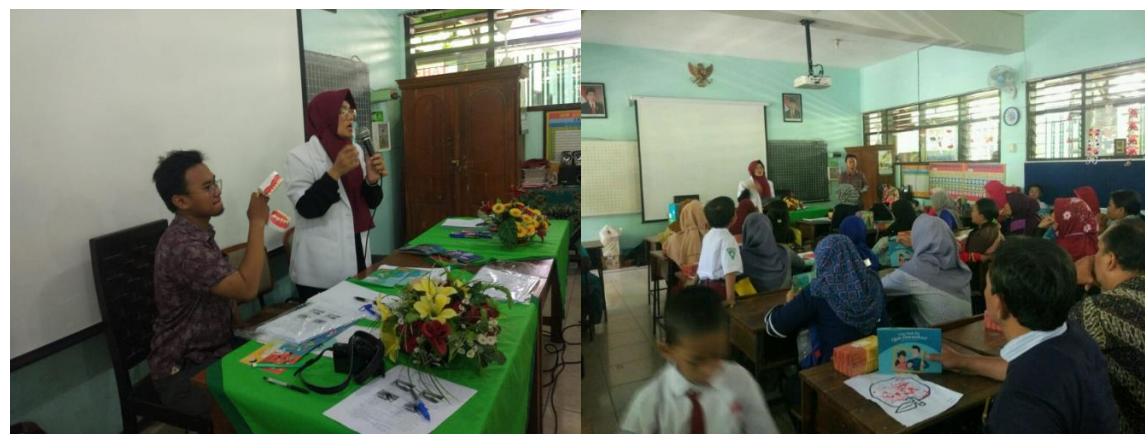

Figure 4. Promotion of illustrated book in Surabayan dialect.

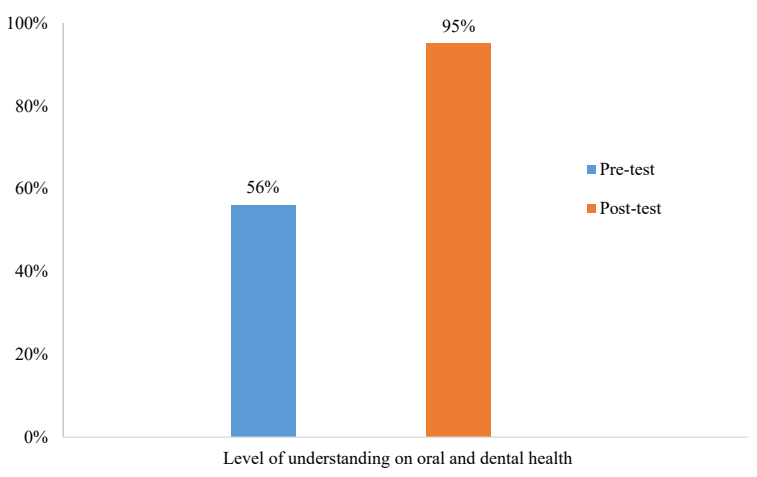

Figure 5. Improvement in the subject matter understanding.

\section{DISCUSSION}

Based on the pre- and post-test comparisons, it was found that $100 \%$ of the participants experienced an increase in their scores and $100 \%$ of the participants had understood the oral health education conveyed through the illustration book. One of them is related to books that are full of color and pictures will be more interesting to read by mothers compared to conventional educational books which only contain text and are not colored. By displaying illustrations related to oral and dental health, mothers will be more interested in reading and remembering the message. In addition, the use of the Surabayan dialect in this book has its own charm so that it can be unique and can increase the reading interest of parents. It is hoped that the use of Surabayan dialect will be easier for mothers to understand because it is the daily language.

Strength of this program is that the Surabayan dialect is able to attract attention and at the same time make it easier for readers who mostly use the Surabayan dialect as their daily language. Based on the results of research conducted by Sulistiono (2016) on the effectiveness of using Javanese language in the promotion of dental and oral health to reduce dental plaque scores at the age of 6-8 years in Sukoharjo, a significant difference was found between the groups that were given promotion of dental health using Javanese and Indonesian, namely the use of Javanese in the promotion of dental and oral health is more effective in reducing plaque scores than the use of Indonesian. ${ }^{10}$

Weakness of this program is that the Surabayan dialect is not a universal language that can be understood by everyone, so this book becomes difficult to understand when given to people who come from outside East Java.The opportunity for this program is that there are still many mothers who think that it is difficult to bring their children to the dentist. It is hoped that this concern can be resolved with increasing awareness of parents about the importance of having their child's teeth checked by a dentist and along with increasing knowledge about dental and oral health, so that mothers will feel that bringing their child to the dentist is an important need to do regularly and not a hard thing. The threat for this program is that not all mothers have an interest in reading and spend time. Mothers who have jobs will not have much free time and feel busy, will be lazy to read this book or just glimpse it because they do not have free time so the material will not be conveyed properly. 
Indonesian Journal of Dental Medicine Volume 3 Issue 2 2020; 33-36

\section{CONCLUSION}

The intervention successfully improved the parents' understandings in the subject matter, and it was expected to motivate parents and their children to have regular dental visits in Keputih Public Health Center. This will have an impact on the oral and dental health in children, which is expected to reduce caries rate in children in the East Surabaya area.

\section{REFERENCES}

1. Profil Sukolilo Kota Surabaya, diakses dari http://sekolah.data.kemdikbud.go.id. Terakhir diakses : Februari 2018

2. 2. Neira D, Pangastuti MD, Huda A, et al. 2017. Gambaran Tingkat Keparahan Karies dan Body Mass Index (BMI) Pada Siswa SDN di Wilayah Kerja Puskesmas Keputih Kota Surabaya. Laporan Epidemiologi PKL Fakultas Kedokteran Gigi Universitas Airlangga

3. Nofarida A, Giffari FZ, Nurazizah A, et al. 2018. Analisis Karakteristik Ibu Terhadap Keputusan Membawa Anak Ke Layanan Kesehatan Gigi Dan Mulut Di Wilayah Keputih Kota Surabaya. Laporan Epidemiologi PKL Fakultas Kedokteran Gigi Universitas Airlangga.
4. Gharlipour, Z., Hazavehei, S. M. M., Moeini, B., Nazari, M., Beigi, A. M., Tavassoli, E., \& Barkati, H. 2015. The effect of preventive educational program in cigarette smoking: Extended Parallel Process Model. Journal of education and health promotion, 4.

5. Bozorgmehr, E., Hajizamani, A., dan Mohammadi, TM. 2013. Oral Health Behavior of Parents as a Predictor of Oral Health Status of Their Children. ISRN Dent, Vol. 2013, Article ID 741783, 5.

6. Lina N, Nila SD. Hubungan Pendidikan, Pengetahuan dan Perilaku Ibu terhadap Status Karies Gigi Balitanya. Dentika Dental Journal 2010;15(1):37-41.

7. Sumerti, NN. 2013. Faktor-faktor yang berhubungan dengan perilaku ibu dalam deteksi dini karies gigi pada anak balita di Kecamatan Kuta Utara Kabupaten Badung. Jurnal Kesehatan Gigi. Vol.1(1):6.

8. Eddy, F. N. A. E., \& Mutiara, H. 2015. Peranan Ibu dalam PemeliharaanKesehatan

9. Halim MP. 2012. Peran orang tua terhadap pemeliharaan kesehatan gigi dan mulut anak dan status kesehatan gigi dan mulut anak kelas II SD St Yoseph 1 Medan. Medan: Universitas Sumatera Utara.

10. Sulistiono, T. 2016. Efektivitas Penggunaan Bahasa Jawa Dalam Promosi Kesehatan Gigi Dan Mulut Untuk Menurunkan Skor Plak Gigi Pada Anak Usia 6-8 Tahun di Mim Klaseman Gatak Sukoharjo. Surakarta: Universitas Muhammadiyah Surakarta. 